\title{
Modeling Determinants of the Dividend Policy of Russian Companies
}

\author{
Anastasia Gukovskaya \\ Department of Finance and Credit \\ Russian State University for the Humanities \\ Moscow, Russia \\ E-mail: gukovskaya.a@rsuh.ru
}

\author{
Mark Mikhaylusov \\ Department of Finance and Credit \\ Russian State University for the Humanities \\ Moscow, Russia \\ E-mail: aventador-mark@yandex.ru
}

\begin{abstract}
The article is devoted to the analysis of dividend policy determinants of Russian non-financial companies. The article relies on a regression analysis of data for MoEx listed companies, dating from 2013 till 2017. As a result the article identifies five determining factors of dividend policy relevant in Russian practice. The authors propose a binary logistic model that allows to model dividend payments. Based on the analysis of empirical data, the article tests this model with a statistically significant result.
\end{abstract}

Keywords—dividends; dividend policy; determinants of dividend policy; binary logistic model; logistic analysis

\section{INTRODUCTION}

The definition of dividend policy determinants in the context of creating a company's value is one of the important areas of theoretical and applied research. F. Modigliani and M. Miller suggested a path breaking hypothesis about the irrelevance of dividends [1]. Questions such as optimal payout strategy are still being debated in modern scholarship [2], [3].

Modern dividend policy theory identifies over twenty main factors influencing the dividend policy of companies. They include, among others, the size of the company, its investment opportunities and the level of profitability of the company. These factors which we review shortly below are in the focus of our analysis.

There is a positive relationship between the size of the company and its dividends. Small companies are reluctant to pay dividends due to asymmetric information and high initial costs for the procedure for issuing securities, while large companies generate a large flow, which allows shareholders to increase dividends [4].

Previous scholarship has empirically proven a negative correlation between the presence of state capital and the size of the net profit distributed for dividends [5]. This is largely due to the fact that in the conditions of uncertainty in the modern economy, companies will prefer to pay high dividends to their private (institutional) shareholders rather than invest in low-income projects. On the other hand, they proved that the higher the cumulative share of the largest shareholders in a company, the greater will be the amount of profit allocated for the payment of dividends. This fact may be due to the fact that several large shareholders find it easier to agree on the amount of dividends. Additionally, the higher the cumulative share of the largest shareholders in a company, the greater the amount of profit allocated for the payment of dividends [6]. In state-owned companies, high dividends are likely for two reasons: managers will strive to demonstrate the company's successful activity to the country's population, the second reason is a reduction in cash flow in the hands of the managerial apparatus, which will reduce potential investment risk, and also entail an increase in budget revenues due to dividend payments [7]. Also in Russian conditions, dividends in state-owned companies can potentially be quite high, since at the legislative level there is a fixed dividend payout ratio of companies with state participation of at least $50 \%$ of the company's net profit. The above works also revealed a negative correlation between the presence of large foreign investors in the company's share capital and the amount of dividends paid by it. This negative trend is manifested in the reluctance of foreign shareholders to share profits with domestic shareholders, which is reflected in the low level of dividends and the preference for foreigners to send retained earnings to invest.

Companies with a high level of leverage tend to retain internal cash flows to meet their credit obligations and protect the interests of creditors, rather than their distribution in favor of the owners [8], [9].

Profitability indicators have a direct impact on the dividend policy of the company. Generally speaking, an increase in dividends correlates with the growth of profitability [7], [8].

The impact of the company's life cycle on its dividend payments is estimated through the indicators RE / TE (ratio of earned capital to total capital) and RE / TA (ratio of earned capital to assets). With the growth of RE / TE, there is a high probability that the company will pay dividends [9]. Mature companies with greater accumulated profits and a sufficient level of self-financing will seek to encourage their shareholders with dividends. At the same time, young companies will seek various sources of financing for their activities, and will not pay dividends at the expense of their development. 
The dividend payout from a previous period influences possible payments in the current period [9], [10]. Once companies begin to pay dividends, they become reluctant to suspend this practice avoiding a possible decrease in share value.

There is a negative correlation between the Tobin coefficient and dividend payments [11]. Companies that have never paid dividends invest in high-yield projects, conduct more R\&D activities, and have a higher Tobin ratio.

Sector affiliation is a pronounced factor in Russia. Companies in the oil, gas, metallurgical and telecommunications industries are paying disproportionately high dividends in comparison to other sectors. Among nonfinancial factors there is a whole block of macroeconomic factors that can have a significant impact on the company's dividend policy: the inflation rate in the country, the gross domestic product, the credit rating of the country in which the company operates, the main stock market indices, the price of oil and the US dollar rate [12].

The inflation effect in the short term on the amount of dividends cannot be unambiguously interpreted only as positive or negative. The potential impact of inflation on the size of dividends can manifest itself as follows: on the one hand, due to increased costs, the company's profit can be reduced and potential dividends will decrease, and on the other hand, in conditions of high inflation and high uncertainty, shareholders will be interested in receiving a larger dividend now, rather than in the future.

The oil price for companies in the oil and gas industry will be one of the main factors of the dividend policy, since the company's operating profit depends on its change, and as a result, the dividends. On the other hand, we can consider the change in oil prices in terms of the cost of purchased fuel and raw materials. In other words, while for the oil and gas industry and exporters, a decrease in oil prices will lead to a decrease in profits, in other industries a decrease in quotations will lead to a decrease in cost and profit, which can also have a beneficial effect on the company's dividends.

The exchange rate of the national currency will also be one of the determining factors for companies oriented to export-import operations. For companies that buy products abroad, a sharp jump in the dollar exchange rate will lead to a drop in profitability, and for export-oriented companies to an increase in profits. Accordingly, a proportional change in dividends will be expected.

No less significant factor in the dividend policy is the level of taxation in the country, namely the ratio of the level of personal taxes and capital gains tax. In a situation where the income tax is greater than the capital gains tax, the shareholder will not be interested in selling the security for a long period. His actions will be associated with the hope of further growth of the paper, with which the potential impact of the capital gains tax will decrease with an increase in the period. This is explained by the fact that the investor will prefer to sell the paper and make a profit in the future, since the dollar is now more expensive than the dollar later. As a result, companies should underestimate dividends so that investors can optimize their tax costs [13].

The structure of share capital, sector affiliation, profitability, the life cycle of a company and its size, the dividends paid out in previous year, financial leverage, and Tobin's ratio are several factors affecting the dividends of companies. The research hypothesis is that these factors are significant for Russian companies paying dividends.

\section{MODEL DESCRIPTION}

To build a model to determine whether the company will pay dividends or not, the authors relied on discriminant and logistic analysis.

The following factors were added to the factors listed above: the natural logarithm of the company's own capital, the stability index of dividend payments and the payment of dividends two years ago.

The empirical base of the study is composed of data from MoEx (Moscow Exchange) listed companies whose shares were included in the MICEX index at the end of each year in the period from 2013 till 2017. The total sample for this period comprises 184 observations.

At the initial analysis stage, the authors carried out a discriminant selection of indicators that were characteristic of payers or dividends payers. The dependent variable was the fact whether the company paid dividends in the reporting period. This variable was assigned a binary value; 4 " if the company paid dividends and $\theta$ " if there were no dividend payments.

At this stage, one of the main features of the company paying the dividend was the profitability of its assets. Financial leverage (Net Debt to EBITDA) was another key feature. Companies with a lower level of debt burden paid dividends more often than companies with a higher leverage level. Another factor selected at the stage of discriminant analysis which characterized dividends payers, was the indicator of the company's life cycle. RE / TA has been consistently higher among dividend payers than non-payers. Mature companies which have large retained earnings, invest less and are prone to pay dividends to their shareholders. Young companies, on the other hand, are investing in their own development. In addition, they have a high level of debt, which reduces the company's ability to pay dividends.

The last two factors that distinguished payers from defaulters were industry affiliation" and type of owner". Companies in the metallurgical, financial and oil and gas sector paid dividends more often than machine-building, transport or retail trade companies. State-owned companies also paid dividends, albeit smaller ones, but more often than private companies.

The remaining determinant factors were in one way or another peculiar to both payers and non-payers of dividends.

Based on discriminant analysis, the authors formed a binary logistic model to evaluate the weights of the factors. 
The selection of this model relies on the binary quality of the dependent variable (the fact of payment of dividends).

The logistic model is described by the formula:

$$
P=\frac{1}{\left(1+e^{-y}\right)}
$$

- where - $\mathrm{P}$ is the probability;

- e -base of natural logarithm;

- $\mathrm{y}$ - logistic regression equation.

The core of the model, with the highest level of correlation with the dependent variable was the fact that dividends were paid in the past period (correlation coefficient 0,62 ).

The following indicators were included in the model: D1: dividend payment in the previous period, D2: presence of dividends 2 years ago, LNTE: natural logarithm of Equity, $\mathrm{MMF}$ - sector affiliation (metallurgic, mining, financial non-banking sectors), ROA - return on assets.

The final binary logistic model is as follows:

$\mathrm{Y}=6,73431+\mathrm{D} 1 * 2,13583+\mathrm{D} 2 * 1,62825+\mathrm{LNTE}^{*} 0,19672+$ MMF*3,21092+ROA*10,67467

(2)

\section{Statistical Tests}

Descriptive statistics of selected factors for this model are presented in "Table I"

TABLE I. DESCRIPTIVE STATISTICS OF THE FACTORS INCLUDED IN THE MODEL

\begin{tabular}{|l|l|l|l|l|}
\hline \multicolumn{1}{|c|}{ Factor } & \multicolumn{1}{|c|}{ MIN } & MAX & Standard deviation & Average \\
\hline D1 & Binary variable & \\
\hline D2 & Binary variable & 30,12 & 5,62 & 24,81 \\
\hline LNTE & 1 & Binary variable & 0,06 \\
\hline MMF & Bin & 0,37 & 0,09 & \\
\hline ROA & $-0,34$ &
\end{tabular}

TABLE II. MODEL FACTOR CORRELATION COEFFICIENTS

\begin{tabular}{|l|l|l|l|l|l|}
\hline & D1 & \multicolumn{1}{|c|}{ D2 } & \multicolumn{1}{|c|}{ LNTE } & MMF & ROA \\
\hline D1 & 1,00 & & & & \\
\hline D2 & 0,67 & 1,00 & & & \\
\hline LNTE & 0,33 & 0,23 & 1,00 & & \\
\hline MMF & 0,07 & 0,08 & $-0,16$ & 1,00 & \\
\hline ROA & 0,19 & 0,15 & 0,20 & $-0,09$ & 1,00 \\
\hline
\end{tabular}

There is no multicollinearity in the model in "Table II", all values of the coefficients are in the range up to 0,9 .

TABLE III. StatisticAl IndicAtors of THE SignifiCANCE OF SELECTED FACTORS

\begin{tabular}{|l|l|l|l|l|}
\hline Variable & \multicolumn{1}{|c|}{ Beta-coefficient } & Standard error & Wald coefficient & P-value \\
\hline Constant & $-6,73431$ & 1,82344 & 13,6396 & 0,0002 \\
\hline D1 & 2,13583 & 0,75328 & 8,0393 & 0,0046 \\
\hline D2 & 1,62825 & 0,72881 & 4,9913 & 0,0255 \\
\hline LNTE & 0,19672 & 0,068163 & 8,3289 & 0,0039 \\
\hline MMF & 3,21092 & 1,33376 & 5,7957 & 0,0161 \\
\hline ROA & 10,67467 & 3,66042 & 8,5045 & 0,0035 \\
\hline
\end{tabular}

Analysis of the statistical significance of factors showed the significance of all parameters of the model in "Table III".

The results of the Nigel Kirk statistics $(0,6652)$ indicate that factors included in the model explain occurring events with a ca. $66,5 \%$ probability. The AUC coefficient was 0,953 , which indicates the good quality of the model.

The HL (Hosmer - Lemeshow) test result $(0,8674)$ is greater than the 0,05-significance level. This indicates that there are no significant differences between observed and expected probabilities of the occurrence of events.

The model accurately determines about $91 \%$ of the events (Table 4). The model determines dividend payers better $(95,97 \%)$ than non-payers $(68,57 \%)$.

TABLE IV. EVENT DEFINITION TABLE

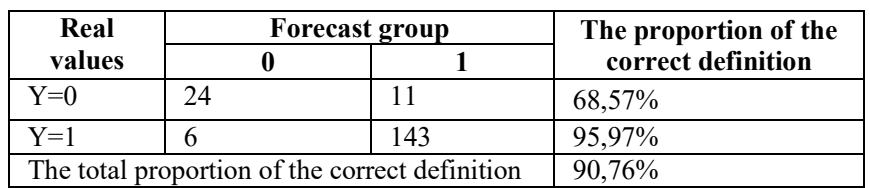

In general, we can talk about the good quality of the model on the basis of the conducted statistical tests and its analytical ability.

The authors applied the model to an analysis of the interim dividend payments of non-financial companies included in the MICEX index by the end of September 2018 as a test of the its predictive power. In addition, there is MoEx, which board of directors decided not to pay interim dividends by some subjective reasons, but the model calculated that MoEx would pay dividends with rather high probability. The obtained logistic model showed a good level of verification in "Table V". 
TABLE V.

Evaluation of THE Probability of PAYMENT OF Dividends By COMPANIES IN 2018

\begin{tabular}{|l|l|l|l|l|l|l|l|}
\hline \multicolumn{1}{|c|}{ Company / Period } & D1 & D2 & LNTE & MMF & ROA & Y-value & Probability \\
\hline Alrosa 1h/y 2018 & 1 & 1 & 26,34 & 1 & $13,30 \%$ & 6,84 & 1,00 \\
\hline MoEx 1h/y 2018 & 1 & 1 & 23,17 & 1 & $0,29 \%$ & 4,83 & 0,99 \\
\hline MMC2Q 2018 & 1 & 1 & 26,56 & 1 & $8,44 \%$ & 6,37 & 1,00 \\
\hline MTC1h/y 2018 & 1 & 1 & 25,45 & 0 & $3,98 \%$ & 2,46 & 0,92 \\
\hline NLMC 2Q 2018 & 1 & 1 & 26,70 & 1 & $9,81 \%$ & 6,54 & 1,00 \\
\hline NMTP 1h/y 2018 & 0 & 1 & 24,76 & 0 & $6,02 \%$ & 0,41 & 0,60 \\
\hline Novatec 1h/y 2018 & 1 & 1 & 27,44 & 0 & $7,57 \%$ & 3,24 & 0,96 \\
\hline NorilskyNikel 1h/y 2018 & 1 & 1 & 26,32 & 1 & $8,36 \%$ & 6,31 & 1,00 \\
\hline Polus 1h/y 2018 & 1 & 1 & 24,41 & 1 & $5,54 \%$ & 5,63 & 1,00 \\
\hline RossiyskiyeSeti 1Q 2018 & 0 & 1 & 28,01 & 0 & $1,34 \%$ & 0,55 & 0,63 \\
\hline Rosneft 1h/y 2018 & 1 & 1 & 29,13 & 0 & $2,75 \%$ & 3,05 & 0,95 \\
\hline Severstal2Q 2018 & 1 & 1 & 26,03 & 1 & $13,81 \%$ & 6,84 & 1,00 \\
\hline Tatneft 2018 & 1 & 1 & 27,39 & 0 & $8,86 \%$ & 3,36 & 0,97 \\
\hline Fosagro 1h/y 2018 & 1 & 1 & 25,38 & 0 & $3,76 \%$ & 2,42 & 0,92 \\
\hline
\end{tabular}

\section{CONCLUSION}

Based on the obtained model, dividend history and financial determinants are identified as significant for the dividend policy of Russian companies.

Firstly, the model includes two factors that take dividend history into account: dividend payments dating from two years ago and dividend payments dating from last year. The presence of dividend payments from years ago improves the company's dividend history and increases the likelihood of payment in the reporting year. If the company began to pay dividends, it is highly likely that it will not abandon this practice.

Secondly, financial determinants such as return on assets and capital structure influence the probability of dividend payments. Companies with near zero or negative profitability rarely pay dividends. The presence of a relatively large equity capital allows the company to maneuver in the area of financing its projects and paying dividends if there is a loss in the reporting period and maintaining a corporate dividend history.

As the model has shown, the company's sector affiliation is important: mining and metallurgical companies along with companies in the financial non-banking sector are more likely to pay dividends than companies in other industries.

\section{REFERENCES}

[1] M.H.Miller, F.Modigliani, Đividend Policy, Growth and Valuation of the Shares", The Journal of Business,1961, vol.34 No.4, pp.411433.

[2] M.Kouiki, M.Guizani,-Ðwnership Structure and Dividend Policy Evidence from the Tunisian Stock Market", European Journal of Scientific Research, 2009, vol. 25 (1), pp.42-53.

[3] E.Fama, K.French, Đisappearing Dividends: Changing Firm Characteristics or Lower Prosperity to Pay", Journal of Financial Economics, 2001, vol.60, pp.3-43.

[4] Ibid. pp. 22-29.

[5] Ibid. P. 34.

[6] S.Sakinc, S.Gungor,-The Relationship between Ownership Structure and Dividend: An Application in Istanbul Stock Exchange", Journal of Economics and Development Studies, 2015, vol. 3, No.4, pp.19-30.
[7] D.Al-Kuwari,-Đeterminants of the Dividend Policy in Emerging Stock Exchanges: The case of GCC Countries", Global Economy \& Finance Journal,2009, vol.2 No.2, pp.38-63.

[8] K.Gugler, and B. Yurtoglu,-Corporate Governance and Dividend Pay-Out Policy in Germany", European Economic Review 2003, No.47, pp. 731-758.

[9] R.Morck, B.Yeung,-Đividend Taxation and Corporate Governance”,Journal of Economic Perspectives, 2005, vol. 19, iss. 3, pp. $163-180$.

[10] Ibid. P. 174.

[11] V.Aivazian, L.Booth, and S.Cleary, Follow Different Dividend Policies from U.S. Firms?", Journal of Financial Research, 2003, No. 266 pp.371-387.

[12] H.De Angelo, L.De Angelo, R.M. Stulz,-Đividend policy and the earned/contributed capital mix: A test of the life-cycle theory", Journal of Financial Economics, 2006, vol. 81, No.2, pp. 227-254.

[13] J.Lintner, - Đistribution of Incomes of Corporations among Dividends, Retained Earnings, and Taxes", The American Economic Review, 1956, No. 46 pp. 97-113. 